\title{
A NYÍREGYHÁZI LAKOSOK DOHÁNYZÁSI SZOKÁSAI
}

\author{
BOKOR ANNA \\ Berencsiné MAdácSi Eszter \\ JÁVORNÉ ERdei RENÁta
}

\begin{abstract}
The individual's state of health is affected not only by environmental influences but also genetic factors and the quality of the health care system. Individuals are also responsible for their state of health and its changing because their health behavior and lifestyle may directly cause or prevent various diseases. Lifestyle is the factor that can be most directly controlled by the individual and has the most influence on overall health status. Smoking is one major component of lifestyle that affects many people and has very harmful effects over time.

Smoking is one of the most serious risk factors for cardiovascular, respiratory and tumor diseases. According to the 2009 data of ELEF, one third (33\%) of the Hungarian population smokes regularly.[1] In Hungary 30,000 people die of smoke-related illnesses, on average 15 years earlier than the non-smokers. Ninety percent $(90 \%)$ of deaths caused by lung cancer and twenty-five percent (25\%) of cardiovascular diseases can be regarded as a consequence of smoking. The risk of heart attack is two to three times higher for smokers compared to non-smokers.[2] In addition to the evaluation of health status another aim of this study is to present data on the health behavior of the Nyíregyháza population with special emphasis on their smoking habits.

Another objective of the research was to bring to the attention of the inhabitants information about the dangers of smoking, different possibilities of stress management and to make the population more committed towards health awareness and better health.
\end{abstract}

Keywords: health awareness, smoking

DOI: $10.19055 / \mathrm{ams} .2013 .4 / 10 / 13$

\section{BEVEZETÉS}

A modern életforma átalakította az ember életkörülményeit, társas viszonyait, környezetét, társadalmi magatartását. Az 1930-as évekig a fertőző, járványokat okozó betegségek töltötték be a vezető haláloki szerepet, ám napjainkra a betegségspektrum lénye- 
ges változáson esett át, melynek egyik oka a járványfolyamatok megfékezése. Javult az általános higiénés helyzet, védőoltásokat és antibiotikumokat fejlesztettek ki, higiénés rendszabályok kerültek bevezetésre, vagyis egyfelöl a mikrobiológia és a közegészségügy fejlödésének köszönhetően történt átalakulás. (PIKÓ 2006)

Másfelöl a modern társadalmakban a korábban jellemző egységes értékrend felbomlott. A társadalomalap egységévé az egyén vált, szinte határtalanná vált az egyéni szabadság a korábbi társadalmi kötöttségekhez képest. Az egyéni önmegvalósításban ez lényeges előrelépést jelentett, viszont az egyén társas kapcsolatait jelentős konfliktusmennyiséggel terhelte meg. Megváltozott a munkaidő és a szabadidő aránya, a fogyasztás vált a legfontosabb társadalmi normává, és csak látszólag az egyén érdekeinek megvalósulása. Az egészséges életvitelt a modern életstílus sok esetben megnehezíti, gyakran nem jut elég idő a sportra, táplálkozáskontrollra, az ember saját lelkének gongozására, a megnövekedett stresszmennyiség pedig a káros szenvedélyek kialakulásának kedvez. (PIKÓ 2006)

A betegségspektrum megváltozása kettős szemléletváltást igényelt a gyógyítók részéről. A fejlődést elsőként a biomedicina kialakulása jelentette, tehát egy természettudományos paradigmaváltás volt. A második viszont egy természettudományos szemléletváltás, amely folyamat jelenleg is zajlik, és elsősorban a magatartástudományokat érinti. A civilizációs betegségek jelentős része az életmódbeli, egészséggel összefüggő magatartásformákra vezethető vissza.

A megnövekedett társadalmi információ a többes értékrend miatt fellépő társadalmi és társas konfliktus stresszként hat az emberi szervezetre. Így a társadalmi szintü folyamatok olyan pszichofiziológiai folyamatokat indítanak el a szervezetben, amelyek változásokat idéznek elö annak működésében, s ha ez tartósan fennáll, betegségek alakulnak ki. (PIKÓ 2006)

A stressz az az élettani folyamat, mely során valamilyen környezeti változás viselkedésváltozásra készteti az egyedet. Eustressz: A mindennapi életben szokásos menynyiségü stressz, amivel az egyén képes megbirkózni. Distressz: Meghaladja a normál alkalmazkodási képességet, tartós élettani változásokat idéz elö, amelyek betegségképzőek lehetnek. (SELYE 1975)

A stressz egyén és környezet kölcsönhatása, önmagában se nem negatív, se nem pozitív, hanem egy alkalmazkodási folyamat, amelynek következményei a végeredménytől függően lesznek. A társadalmi tényezők által generált betegségfolyamatokat szociopszichoszomatikus patomechanizmusnak nevezzük. (PIKÓ 2006)

\section{AZ EGÉSZSÉGI ÁLLAPOT EGYENLŐTLENSÉGEI ÉS A TÁRSADALMI STÁTUSZ}

A XX. században a közegészségügyi helyzet javulásával, és a fertőző betegségek okozta járványok megszüntetésével a fejlett országok halálozási statisztikái kedvezően változtak. Ennek mértéke azonban eltérő volt Európa különböző országaiban: Nyugat-Európában a születéskor várható átlagos élettartam, a halálozási arányszámok, valamint az egészségi állapot egyéb indikátorai terén lényeges javulást sikerült elérni az utóbbi évtizedekben, viszont a kelet-európai térségben, tehát Magyarországon is, a tendencia 
nem volt hasonlóan kedvező, az 1960-as évektől romló tendencia figyelhető meg. (PIKÓ 2002)

A Black-riport, ami a vizsgálatokban élen járó Nagy-Britanniában készült, megállapította, hogy a brit társadalomban az egészségi állapot szintjén az egyenlötlenségek széles körüen jelen vannak, és nemtől függetlenül egyre inkább növekednek szinte valamennyi életkorú népességi csoportban. Ez a jelenség kimutatható bármely társadalmi indikátor alkalmazásával. Ennek egyik oka lehet, hogy a nyugati társadalmakban a foglalkoztatás, az iskolázottság, és a jövedelmi-vagyoni helyzet egymással szoros összefüggésben van. Az elsősorban a foglalkozáson és képzettségen alapuló, brit Anyakönyvi Hivatal által alkalmazott társadalmi rétegződési modell osztálykategóriáit összehasonlítva kimutatható, hogy az I. kategóriától (vezető értelmiségiek, menedzserek) az V. kategória felé haladva a halálozási és megbetegedési arányszámok fokozatos növekedése. (TOWNSED és DAVIDSON 1982)

Ám az egyenlőtlenség nem feltétlenül azt jelenti, hogy valamennyi betegség elöfordulása az alacsonyabb társadalmi rétegek felé mutat törvényszerü növekedést. Az amerikai lakosság egyik kiemelt népegészségügyi problémája, az emlődaganat, évtizedek óta nagyobb arányban fordul elő a kedvezőbb társadalmi helyzetű nők között. Az 1-11 éves gyermekek körében a látászavarok és a hallószerv megbetegedéseinek elöfordulása U-alakú görbét mutat: a közepes jövedelmi helyzetủ rétegeknél a legalacsonyabb ezek előfordulása, és mind a magas, mind pedig az alacsonyabb jövedelmü családoknál magasabb. Az alacsonyabb társadalmi helyzetből adódó hátrányok (egészségmagatartás, lakásviszonyok, táplálkozás, stressz, egészségügyi ellátottság) megmagyarázzák a nagyobb előfordulást. A magas iskolázottságú, kiemelkedő társadalmi-gazdasági helyzetü, gyakran vezető beosztásban dolgozó nők gyermekvállalása egyre jobban kitolódik, tehát a biológiai kockázat növekedésével kell számolni. (PIKÓ 2002)

Az egészségi állapot és a társadalmi helyzet komplex jelenségek, ezért több dimenzióra bontva elemezhetők. A kérdéskör egyik pólusán a társadalmi helyzet, a másikon pedig az egészségi állapot összetettségének elemzése áll. (PIKÓ 2002)

\section{HÁTRÁNYOS HELYZETŰEK}

Mint korábban is láthattuk, az 1982-es brit vizsgálat alapján a vezető értelmiségiek, menedzserek kategóriája felől a szakképzetlen fizikai munkások kategóriája felé haladva a halálozási és megbetegedési arányszámok fokozatos növekedése volt látható. (TOWNSED és DAVIDSON 1982)

Gyakran generál a társadalmi helyzet egészségi állapotbeli különbségeket, ami azután tovább erősítve a folyamatot visszahat a szociális viszonyokra. (PIKÓ 2002)

A magasabb végzettségủek között alacsonyabb számban fordult elő cukorbetegség, magas vérnyomás, májzsugor krónikus légzőszervi betegségek, gyomorfekély, vérzékenység, mozgásszervi korlátozottság, epe- és vesebetegségek. Tehát ezek betegségek jobban érintik az alacsonyabb végzettségüeket, valamint az alacsonyabb iskolai végzettségü és társadalmi státusú emberek a foglalkozási megbetegedések szempontjából is fokozottabban veszélyeztetettek. (PIKÓ 2002) 
Azok a környezeti és életmódbeli tényezők, melyek a daganatképzést segítik elő, gyakrabban fordulnak elő az alacsonyabb társadalmi státusban levők között.

Ismert tény, hogy a dohányzás nagyobb mértékben fordul elő az alacsonyabb iskolázottságú, alacsonyabb társadalmi státusú lakosság körében. Az önkárosító magatartásformák a konfliktusmegoldás módszerei, bár kevésbé hatásosak. (PIKÓ 2002)

\section{ÉLETMÓD, EGÉSZSÉGMAGATARTÁS}

Az életmód befolyásolja az egészséget, az életkilátásokat, felelős a betegségek kialakulásáért, és szinte minden, egészséggel és betegséggel kapcsolatos véleményre hatást gyakorol. Jól körülhatárolt, konkréttevékenységi körökben nyilvánul meg, azokat a magatartási elemeket foglalja magába, melyek a mindennapi életet jellemzik, szó szerint az élet vitelét jelenti. Az életmód tárgyiasult formái azok a tárgyak, amelyekkel magunkat körülvesszük. Az életmód magatartásbeli és mentális elemei pedig a szabadidő eltöltésétől kezdve a mindennapi életünkről való gondoskodáson át az egészséggel összefüggő magatartásformákig terjednek. (PIKÓ 2006)

Az egészséggel kapcsolatos életmód olyan kollektív magatartási minták összessége, amelyek az egyének társadalmilag befolyásolt életesélyeik közvetítette választásokon alapulnak. A társadalmi befolyás alatt nem kizárólag a társadalmi - gazdasági helyzet viszonyait kell érteni, hanem például a nem vagy az életkor hatását is, amelyek közismerten és igazoltan hatással vannak az egészségmagatartásra, így az egészségi állapotra is.

Az egészséggel kapcsolatos életmód a következő magatartási elemeket tartalmazza: káros szenvedélyek, táplálkozási szokások, fizikai aktivitás és rekreáció, az egészség megőrzéséért végzett tevékenységek, alvási szokások. (PIKÓ 2006)

Egészségmagatartásnak nevezzük az egészséggel kapcsolatos magatartásformák összességét. Két alaptípus jellemző, az egyik az egészség megtartását szolgáló preventív egészségmagatartás, más néven immunogén egészségmagatartás. Ilyen lehet a rendszeres sportolás, egészséges táplálkozás, autóban a biztonsági öv használata, stb. A másik a patogén egészségmagatartás, vagyis egészségkockázati magatartás. Ide tartoznak többek között a káros szenvedélyek is.

Az immunogén egészségmagatartás lehet passzív, amikor egyszerüen arról van szó, hogy nem tesz káros dolgot az egészsége szempontjából, például tartózkodik a drogfogyasztástól, és lehet aktív, ami tudatos döntés eredménye, és aktív hozzáállást is kíván, mint például a sportolás. (PIKÓ 2006)

Az egészségmagatartást befolyásoló tényezők közül jelentős szerepük van a társadalmi tényezőknek, társadalmi normáknak. Az egészség, mint érték jelentőségének felismerése, hangsúlyozása, mivel az egészség különböző helyet foglal el a különböző társadalmi rétegek értékrendjében. Néhány egészségmagatartási elem, mint például a táplálkozás és a fizikai aktivitás erösen kapcsolódnak a gyermekkori családból hozott szokásrendszerhez. (PIKÓ 2006) 


\section{RizikómagataRTÁs}

Az egészségi rizikómagatartás olyan magatartásminták sorozata, amelyek intenzitásuk vagy tartósságuk következtében válnak az egészségre kockázatossá. (www.kk.pte.hu/) Ilyen, egészségre kedvezőtlen magatartásformák az élet minden területén felléphetnek. Táplálkozásnál rizikómagatartás például a magas kalóriatartalmú és magas zsírtartalmú ételek túlzott fogyasztása, vagy a fóétkezések közötti nassolás. Szexuális rizikómagatartások közé tartozik az óvszer és más fogamzásgátló eszközök használatának mellözése, a gyakori partnerváltoztatás. A fizikai aktivitásnál nemcsak a mozgásszegény életmód (például ülőmunka), hanem a túlzott mértékü, vagy megerőltető fizikai aktivitás és a veszélyes sportok is rizikómagatartásnak számítanak. Az addikciók (pl.: dohányzás, túlzott alkoholfogyasztás, kábítószer-függőség) is a rizikómagatartás megjelenési formái. Károsíthatja az egészséget a higiénés szabályok be nem tartása is. A külső megjelenéssel kapcsolatosan is jelentkeznek rizikómagatartás-formák: a túlzott napozás, szolárium használat, valamint az anabolikus szteroidok alkalmazása a test izomtömegének növelésére. Rizikómagatartás a közlekedési szabályok be nem tartása, a szükségtelen, vagy helytelen gyógyszerszedés, az orvoshoz fordulás késleltetése, stb. (URBÁN 2001)

\section{DOHÁNYZÁS}

A dohányzás olyan tanult szokás, mely átszövi a mindennapi élet viselkedésvilágát, és örömre, bánatra, a kihívásokra adott torzult és az egészséget fenyegető választ vált ki.

Dohányzás következtében, világszerte évente kb. 5 millió ember hal meg napjainkban, azaz 6 másodpercenként egy ember.

A dohányzás ártalmaira annak elterjedésével egy időben elkezdték felhívni a figyelmet. Mégis a dohányipar az egyik legsikeresebb iparág, a cigaretta élvezete az egyik legelterjedtebb legális drogélvezet.

A dohányzásról leszokni, ha már rászokott valaki, nagyon nehéz. Leggyakrabban betegség, vagy nők esetében várandósság miatt szoknak le. (http://color.oefi.hu/adat) A dohányzás az egyik legjelentősebb környezetszennyező tényező: szennyezi a környezeti levegőt, passzív dohányzásra kényszerít és szennyezi a környezetet az elhasznált, elszívott cigaretta maradékával, a csikkel.

Magyarországon évtizedek óta kiemelkedően magas az egy főre jutó cigarettafogyasztás. Az 1990-es években a világ vezető dohányfogyasztói között voltunk. Az Egészségügyi Világszervezet HFA adatbázisa szerint a hetvenes évek óta az évi ciga rettafogyasztás több, mint 2000 szál cigaretta (a legális kereskedelemben eladott cigaretta mennyisége elosztva a teljes népességgel). 1970-től az évi 2100 szálról 1993-94re elértük a 2700 szál/év/fö csúcsot, azóta csökkenő a trend. (http://color.oefi.hu/adat) A középkorú férfiak körében a szív- és érrendszeri halálozások egyharmada, a rákhalálozások közel fele, a légzörendszeri betegségek okozta halálozások kétharmada a dohányzásnak tulajdonítható. 
Magyarországon az 1970 és 1999 közötti időszakban mintegy 800 ezer halálozás a dohányzás miatt következett be, ami azt jelenti, hogy az utóbbi három évtizedben dohányzás okozta minden ötödik ember halálát.

A férfiak halálozásainak 28 , a nők halálozásainak mintegy $9 \%$-a dohányzásspecifikus mortalitás. 1970-ben 20 ezer, 1999-ben több mint 28 ezer ember halt meg a dohányzás következtében. Ezalatt az időszak alatt a dohányzás okozta halálozás 19\%-kal nőtt, miközben a dohányzástól független, egyéb okokból származó halandóság több mint $9 \%$-kal csökkent. Az egész népességre számított dohányzásspecifikus, standardizált halálozási arány 1999-ben kétszerese volt az EU (2004. május 1. előtti) országaira számított átlagnak. (http://color.oefi.hu/adat)

\section{EREDMÉNYEK BEMUTATÁSA}

A teljes Életminőség - Háztartáspanel kérdőív kiterjed a háztartások jellemzőire, gazdasági aktivitásra, egészségi állapotra, társas kapcsolatokra, idősek helyzetére, a támogató rendszerek - szociális problémák témakörére, a Szociális Iroda müködésére és biográfiára.

Az egészségi állapot témaköre a korábbi évekhez képest (egészségi állapot megítélése, tartós betegségek) a 2012-es kérdőívben több kérdéssel is bővült az Európai Lakossági Egészségfelmérés mintája alapján, így az adatok összehasonlíthatóak az ELEF/OLEF adatokkal.

Jelen tanulmányban a szubjektív egészségi állapotot, valamint az egészségi állapot témakörén belül a dohányzási szokásokat elemeztük.

Kutatásunkban a következő kérdéseket elemeztük:

1. Dohányzók és nemdohányzók aránya Nyíregyházán, nemek szerint megoszlás

2. A dohányzók és nemdohányzók korcsoportonkénti megeloszlása Nyíregyházán.

3. A rendszeresen dohányzók aránya országos szinten $(2003,2009)$ és Nyíregyházán (2012) nem és életkor szerinti eloszlásban.

4. Dohányzók-nemdohányzók aránya Nyíregyházán, körzetek szerint.

5. Passzív dohányzás Nyíregyházán

Az adatok elemzése az SPSS for Windows, és Microsoft Excel programmal történt. 
1. ábra Dohányzók és nemdohányzók aránya Nyíregyházán, nemek szerint és együtt, $2012(\%)$

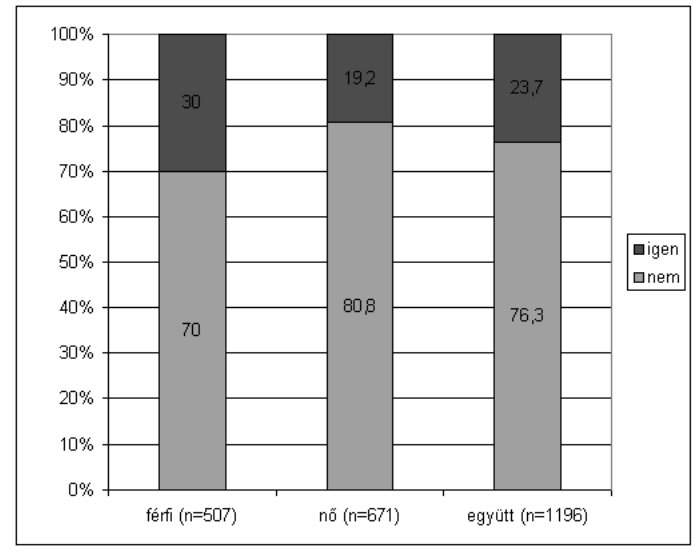

Dohányzással kapcsolatban elsőként a dohányzók-nemdohányzók arányát vizsgáltuk, az 1227 kitöltött kérdőívböl erre a kérdésre 1196 értékelhető válasz született, 31 kérdöívben erre nem adtak választ. Nyíregyházán a lakosság 17.8\%-a dohányzik napi rendszerességgel, 5.9\%-a alkalmi dohányos és 76.3\%-a nem dohányzik. Az ELEF 2009-es adatai alapján $(31.4 \%$ a dohányzók aránya, ők nagyrészt napi rendszerességgel dohányzók) megállapíthatjuk, hogy a 2012-re Nyíregyházán csökkent a dohányzók aránya (23.7\%) a 2009-es országos átlaghoz képest.

A férfiak nagyobb arányban dohányoznak (30\%), 23.9\%-uk naponta, $6.1 \%$-uk alkalmanként dohányzik. A nőknél lényegesen kevesebb, 19.2\% a dohányzók aránya, napi rendszerességgel 13.7\%-uk, az alkalomszerủen 5.5\%-uk dohányzik. A továbbiakban (és az alábbi ábrán is) a napi rendszerességgel dohányzókat és az alkalmanként dohányzókat egy kategóriába soroljuk (dohányzók), ahogy az ELEF 2009-es felmérés adataiban is használják. (1. ábra)

Következőnek azt vizsgáltuk, hogy milyen a dohányzó, illetve a nemdohányzó lakos ság életkori eloszlása.1132 kérdőívben adtak választ mindkét kérdésre.

A nemdohányzók körében jelentősen több az idősek aránya (22.4\%), ennek megfelelően kisebb arányban vannak fiatalok (17.3\%) és középkorúak (60.2\%) a dohányzóknál $(24.3 \%$ és $69.5 \%)$.

A 2. ábra jól mutatja, hogy a dohányzók között mennyire kevés $(6.3 \%)$ a 65 év fölöttiek aránya. Ennek valószínú oka, hogy a dohányzók átlagosan 15 évvel rövidebb ideig élnek, mint nemdohányzó kortársaik. (Népegészségügyi jelentés 2012) 
2. ábra A dohányzók és nemdohányzók korcsoportonkénti eloszlása Nyíregyházán, 2012 (\%)

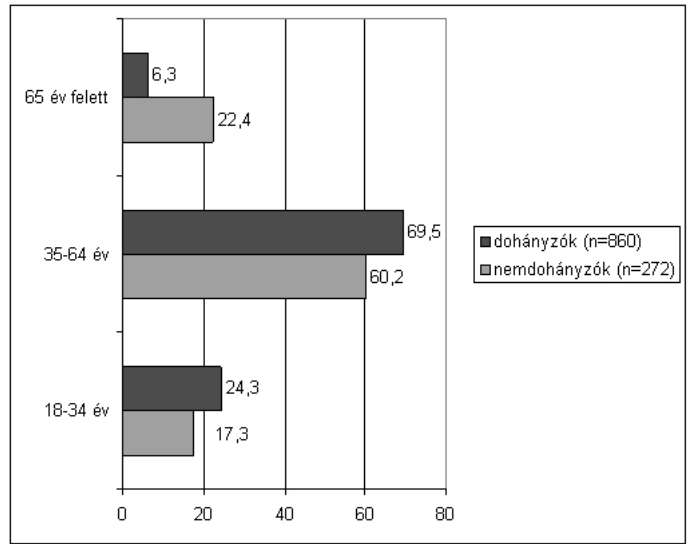

1. Táblázat: A rendszeresen dohányzók aránya országos szinten $(2003,2009)$ és Nyíregyházán (2012) nem és életkor szerinti eloszlásban (Forrás: Egészségfelmérés

(ELEF), 2009. Statisztikai tükör IV. évfolyam, 50.szám)

\begin{tabular}{|l|l|l|l|l|}
\hline \multirow{2}{*}{ Nem } & \multirow{2}{*}{ Évszám, kutatás } & \multicolumn{3}{|l|}{ Életkor } \\
\cline { 3 - 5 } & & $18-34$ év & $35-64$ év & 65 év felett \\
\hline Nők & 2003 OLEF & $32.5 \%$ & $28.5 \%$ & $5.3 \%$ \\
\hline & 2009 ELEF & $25.6 \%$ & $28.8 \%$ & $7.0 \%$ \\
\hline & 2012 Nyíregyháza & $25.0 \%$ & $21.1 \%$ & $7.80 \%$ \\
\hline Férfiak & 2003 OLEF & $43.1 \%$ & $39.0 \%$ & $15.9 \%$ \\
\hline & 2009 ELEF & $36.3 \%$ & $36.4 \%$ & $14.1 \%$ \\
\hline & 2012 Nyíregyháza & $38.4 \%$ & $33.10 \%$ & $8.80 \%$ \\
\hline
\end{tabular}

Megvizsgáltuk a dohányzók arányát életkori eloszlás alapján, nemek szerint és összehasonlítottuk a korábbi lakossági egészségfelmérések adataival. 522 férfi és 597 nő válaszait, tehát 1197 kérdőív adatait tudtuk vizsgálni ennél a kérdésnél. (1. táblázat)

A férfiaknál a legfiatalabb korcsoportban (18-34 év) többen dohányoznak, mint a korábbi években, a 34-64 éves korosztálynál fokozatos, enyhe csökkenés látható, a 65 év fölöttieknél javulás figyelhető meg. 
A nők körében sem mondható el 18-34 éves korosztályban lényeges csökkenés a dohányzók arányát tekintve. A 35-64 évesek között a legnagyobb mértékü a dohányzók arányának csökkenése. A 65 év fölöttieknél megfigyelhető, enyhén növekedő tendencia további minimális emelkedést mutat.

3. ábra Dohányzók-nemdohányzók aránya Nyíregyházán, körzetek szerint, 2012 (\%)

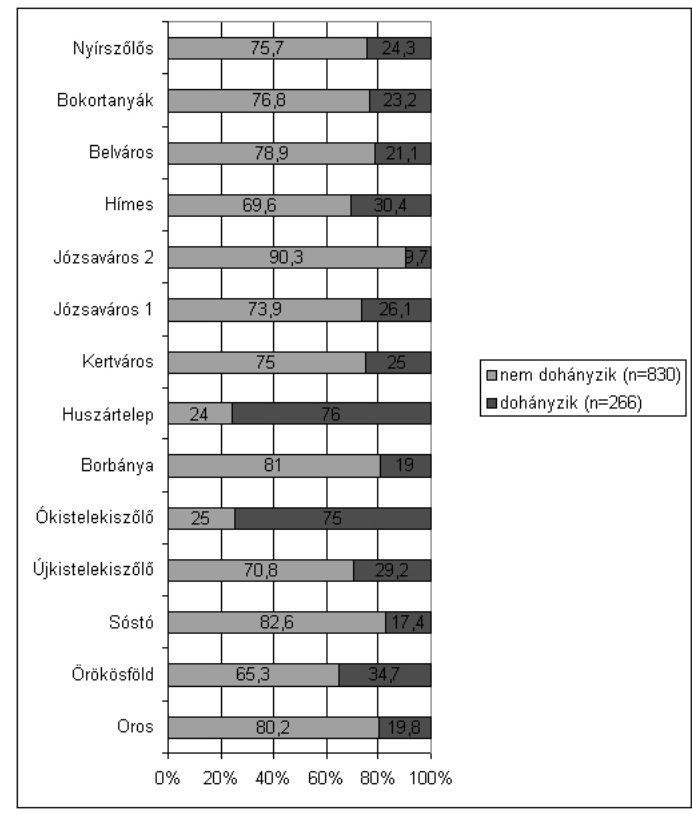

Feltételeztük, hogy Nyíregyháza azon városrészeiben, ahol nagyobb arányban vannak jelen hátrányos helyzetüek a lakosság körében, magasabb a dohányzók aránya. Keresztábra elemzéssel vizsgáltuk, hogy az egyes körzetekben a dohányzók aránya megegyezik-e a nyíregyházi átlaggal. Ennél a kérdésnél 1096 kérdőívet tudtunk elemezni. A Kertvárosban (25\%), Józsaváros1 körzetben (26.1\%), a Belvárosban (21.1\%), a Bokortanyákon (23.2\%) és Nyírszőlősön (24.3\%) az átlaghoz közeli a dohányzók aránya. (3. ábra)

A városi átlagtól többen dohányoznak Örökösföldön (34.7\%), Újkistelekiszőlőn (29.2\%) és Hímesben (30.4\%). Nagyon nagy arányban dohányoznak Ókistelekiszőlőn (75\%) és a Huszártelepen (76\%). Feltételezésünk helyesnek bizonyult, ugyanis ebböl a két városrészekböl kerül ki jellemzően a nyíregyházi hátrányos helyzetü lakosság nagy része. Oroson (19.8\%), Sóstón (17.4\%) és Borbányán (19\%) a városi átlagtól kedvezőbb a dohányzók aránya, a legkevesebben Józsaváros 2 körzetben dohányoznak, itt mindössze $9.7 \%$ a dohányzók aránya. 
4. ábra Milyen gyakran tartózkodik olyan helyen, ahol mások dohányoznak?

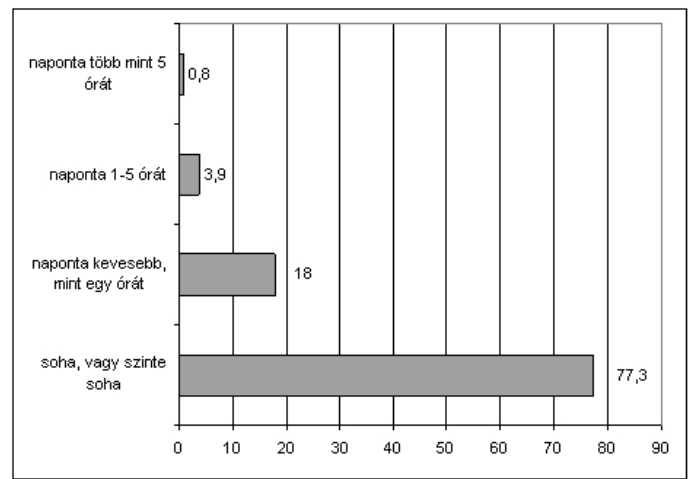

A passzív dohányzás alakulása látható a következö kördiagramon. 1166 kérdőívben adtak választ a kérdésre. A megkérdezettek 77.3\%-a válaszolta azt, hogy soha, vagy szinte soha nem tartózkodik olyan helyen, ahol mások dohányoznak. A megkérdezettek 22.7\%-a naponta ki van téve a passzív dohányzás ártalmainak. Ez nagyon kedvezö, hiszen a '90-es évek végén majdnem fordított volt ez az arány, ám teljes megelégedettségre az adna okot, ha senkinek nem kellene akaratán kívül dohányfüstöt szívnia. (4. ábra)

\section{ÖSSZEFOGLALÁS}

A dohányzás, a dohányzás okozta megbetegedések és halálozások világméretü problémát jelentenek, továbbá a dohányzás okozta gazdasági terhek jelentős problémát okoznak a társadalomban. A WHO szerint szerte a világon több, mint 1,1 milliárd ember dohányzik, a dohányzás okozta halálozás a világon csaknem négyszeresére nőtt az elmúlt negyven év alatt. Bár a dohányzás visszaszorításának érdekében tett intézkedések, törvényi tiltások kedvező hatásúnak bizonyulnak, a dohányzók aránya a Nyíregyházi lakosság körében is még magasnak mondható. Különösen a fiatalok körében láthatjuk azt a sajnálatos jellemzőt, hogy a további korosztályokkal ellentétben, körükben nem figyelhető meg csökkenő tendencia a dohányzás előfordulása terén. Többek között ez az eredmény is azt mutatja számunkra, hogy a dohányzás megelőzésére, továbbá a dohányzásról való leszoktatásra célzott akciókat kell kidolgozni és megvalósítani. A további elemzések birtokában bízunk benne, hogy olyan programokat tudunk kifejleszteni és megvalósítani, első ütemben, azokban a városkörzetekben, ahol kifejezetten magas a dohányosok aránya, melyek mérhető pozitív eredményt fognak hozni a soron következő lekérdezések idejére. 


\section{Felhaszálet irodalom}

Egészségfelmérés (ELEF), 2009. Statisztikai tükör IV. évfolyam, 50.szám http://color.oefi.hu/adat (Országos Egészségfejlesztési Intézet honlapja, Látogatva: 2013. 03.25.)

http://color.oefi.hu/hatas0.htm (Országos Egészségfejlesztési Intézet honlapja, Látogatva: 2013. 03.25.)

http://color.oefi.hu/hatas6.htm (Országos Egészségfejlesztési Intézet honlapja, Látogatva: 2013. 03.25.)

http://www.ksh.hu/nepszamlalas/tablak_teruleti_15 (Népszámlálás 2011. Látogatva: 2013.04. 10.)

JÓNA GY., JÁVORNÉ ERDEI R. (2012): A szubjektív egészségi állapot meghatározó tényezői Nyíregyházán. In: FÁBIÁN G., PATYÁN L., HUSZTI É.: Életminőség Nyíregyházán 2008-2010. Nyíregyháza: START Nonprofit kft.

KOPP M., KOVÁCS M.(2006): A magyar népesség életminősége az ezredfordulón, Budapest: Semmelweis Kiadó

LÁZÁR E. (2009): Kutatásmódszertan a gyakorlatban az SPSS program használatával. Kolozsvár: Scientia Kiadó

MALAKUCZINÉ PÓKA M. (2012): Nyíregyháza lakosságának főbb jellemzői. In: FÁBIÁN G., PATYÁN L., HUSZTI É.: Életminőség Nyíregyházán 2008-2010. Nyíregyháza: START Nonprofit kft.

MIHÁLYI P. (2003): Bevezetés az egészségügy közgazdaságtanába Veszprém: Veszprémi Egyetemi Kiadó

Népegészségügyi jelentés: Jelentés az Országgyülés részére az Egészség Évtizedének Népegészségügyi Programja 2011- évi előrehaladásáról (2012)

Országos Epidemiológiai Központ (2003): Népegészségügyi Jelentés 2003. szakértőknek

PIKÓ B. (2002): Egészségszociológia. Budapest: Új Mandátum Kiadó

PIKÓ B. (2006): Orvosi szociológia. Budapest: Medicina Kiadó

SELYE, H. (1975): Confusion and controversy in stress field. Journal of Human Stress, 1, 33-44

SAJTOS L., MITEV A. (É.N.) : SPSS kutatatás és adatelemzés kézikönyv. Budapest: Alinea Kiadó

TOWNSED, P. és DAVIDSON, N. (1982): Inequalities in health. The Black Report. Harmondsworth: Penguin

URBÁN R. (2001): Útban a magatartásszempontú egészségpszichológia felé: az egészségmagatartás pszichológiai elemzése. Magyar pszichológiai szemle LVI. 4. 593-622

www.kk.pte.hu/servlet/download?type=file\&id=1116 (Pécsi Tudományegyetem honlapja, Látogatva: 2013.04.15.) 